\title{
Pengaruh Pola Asuh Orang Tua Terhadap Kemandirian Anak Kelompok B Taman Kanak-Kanak PGRI Gerunung Tahun Pelajaran 2017/2018
}

\author{
Baiq Haeriah \\ Taman Kanak-kanak PGRI Gerunung \\ baiqhaeriah30@gmail.com
}

\begin{abstract}
Abstrak; Perumusan masalah dalam penelitian ini adalah "Pengaruh Pola Asuh Orang Tua Terhadap Kemandirian Anak kelompok B TK PGRI Gerunung Kecamatan Praya Kabupaten Lombok Tengah tahun pelajaran 2017/2018. Penelitian ini adalah jenis penelitian kuantitatif, populasi dalam penelitian ini adalah keseluruhan siswa kelompok B dengan jumlah 15 orang anak teknik pengambilan sampel dalam penelitian ini adalah Total Sampling yaitu pengambilan sampel secara keseluruhan karena jumlah populasi hanya 8 orang anak ( sampel total). Dalam mengambil data yang diperoleh peneliti menyebar angket dengan skala 5 alternatif jawaban yaitu sangat setuju, ragu-ragu, tidak setuju dan sangat tidak setuju. Analisis data yang digunakan adalah Korelasi Product Moment. Berdasarkan hasil analisis data dengan statistic $\mathrm{r}$ product moment diperoleh nilai rxy sebesar -+ 0,77 selanjutnya dikonsultasikan dengan $r$ tabel dengan $\mathrm{N}=20$ dalam taraf signifikansi 5\% dan 1\% yaitu 0,444 dan 0,561.Dapat disimpulkan bahwa $\mathrm{r}$ hitung lebih besar dari rtabel atau 0,444 <+ 0,77>0,561. Dengan demikian, hipotesis yang menyatakan "Ada Pengaruh Pola Asuh Orang Tua terhadap Kemandirian Anak di kelas Kelompok B TK PGRI Gerunung Praya tahun pelajaran 2017/2018 "diterima karena sudah teruji kebenarannya baik pada taraf signifikansi $5 \%$ dan $1 \%$.
\end{abstract}

Kata Kunci: Pola Asuh, Kemandirian, Taman Kanak-Kanak PGRI.

\section{Pendahuluan}

Keluarga adalah unit terkecil dari masyarakat yang terdiri atas kepala keluarga dan beberapa orang yang terkumpul dan tinggal di suatu tempat di bawah suatu atap dalam keadaan saling ketergantungan. Ketergantungan tersebut dapat memiliki peran penting dari lembaga formal dan non formal. Pendidikan pertama yang diperoleh oleh anak didik adalah pendidikan dari orang tua. Mengingat kelekatan anak (terutama pada anak usia dini) dengan orang tua dan waktu terbanyak anak juga di lingkungan keluarga. Peran vital ini seharusnya dibarengi oleh upaya menjadikan keluarga sebagai tempat yang kondusif bagi berkembangnya semua aspek kemampuan anak. Setiap keluarga perlu didorong memberikan suasana harmonis dan menyenangkan bagi belajar anak dirumah. Sehingga keharmonisan hubungan keluarga harus ada sebagai syarat mutlak demi keberhasilan anak didik.

Anak mulai belajar dari orang-orang terdekatnya terutama orang tua. Orang tua merupakan guru yang utama dan pertama bagi anak. Segala tingkah laku, kepribadian, maupun gaya hidup orang tua dapat ditiru oleh anak-anaknya. Bukan hanya hal positif saja, namun hal negatif pun dengan polosnya akan ditiru karena pada masa itu anak belum dapat membedakan mana hal yang baik dan tidak baik. Maka dari itu, pentingnya pola asuh yang dilakukan oleh orang tua terhadap pembentukan kepribadian maupun karakter anak.

Adapun tipe-tipe pola asuh yakni pola asuh otoriter, pola asuh otoratif, pola asuh permisif, dan pola asuh penelantaran. Pola asuh otoriter, yaitu pola asuh yang memasang batasan-batasan yang ketat, merapkan paksaan dan hukuman serta pada umumnya meyakini bahwa anak harus patuh kepada orang secara total. Dalam pola asuh ini, anak tidak diberi kesempatan untuk memperoleh haknya. Pola asuh otoratif, yaitu pola asuh yang menerapkan aturan-aturan dan batasanbatasan seperti pola asuh otoriter. Namun, standar yang dibuat jelas diketahui anakanaknya, terbuka, responsif dan memahami kebutuhan anak. Pola asuh permisif, yaitu pola asuh yang memberikan kebebasan anak untuk melakukan sesuatu tanpa pengawasan 
yang cukup. Dalam pola ini, anak berhak menentukan apa yang akan ia lakukan dan orang tua memberikan fasilitas sesuai keinginan anak. Pola asuh penelantar yaitu, pola asuh minimnya bahkan tidak adanya kepedulian orang tua terhadap urusan dan kepentingan anak-anaknya. Bukan berarti orang tua tidak memenuhi kebutuhan anaknya. Hanya saja, orang tua tidak memberikan dorongan emosional.

Masing-masing pola asuh yang diterapkan memberikan efek yang berbedabeda terhadap kemandirian perkembangan anak. Usia dini adalah usia yang sangat penting bagi tumbuh-kembang anak (the golden age) sehingga dibutuhankan pola asuh yang baik dari orang tua anak. Latar belakang yang berbeda akan membentuk pola asuh yang berbeda dan diprediksi dari pola asuh orang tua yang berbeda-beda dapat mempengaruhi kemandirian anak.

Kemandirian anak merupakan suatu kemampuan berfikir, merasakan, serta anak melakukan sesuatu atas dorongan diri sendiri dan mampu mengatur diri sendiri sesuai dengan kewajinammya dalam kehidupan sehari-hari tanpa dibantu oleh orang lain. Ciriciri kemandirian anak usia dini adalah sebagai berikut: kepercayaan pada diri sendiri; motivasi instrinsik yang tinggi; mampu dan berani menentukan pilihan sendiri; kreatif dan inovatif; bertanggung jawab menerima konsekuensi yang menyertai pilihannya; menyesuaikan diri dengan lingkungan; dan tidak tergantung kepada orang lain. Seperti halnya kondisi psikologis yang lain, dapat berkembang dengan baik jika diberikan kesempatan untuk berkembang melalui latihan yang dilakukan secara terus menerus dan dilakukan sejak dini.

Berdasarkan dari observasi awal di Taman Kanak-kanak PGRI Gerunung, ditemukan ada anak yang mandiri dan tidak mandiri. Hal ini mendorong penulis untuk mengadakan penelitian tentang pengaruh orang tua terhadap kemandirian anak usia dini dalam belajar disekolah Taman Kanak-kanak PGRI Gerunung.

\section{Permasalahan}

Rumusan masalah penelitian ini adalah "Adakah Pengaruh Pola Asuh Orang Tua terhadap Kemandirian Anak Kelompok B di Taman Kanak-kanak PGRI Gerunung tahun Pelajaran 2017/2018?".

Tujuan penelitian ini adalah untuk mengetahui ada tidaknya Pengaruh Pola Asuh Orang Tua terhadap Kemandirian Anak Kelompok B di Taman Kanak-kanak PGRI Gerunung tahun Pelajaran 2017/2018.

\section{Kajian Teori}

Pola asuh secara etimologis berasal dari kata pola dan asuh. Dalam kamus umum bahasa Indonesia kata pola berarti model sistem cara kerja (bentuk struktur yang tepat), sedangkan kata asuh mengandung arti menjaga, merawat, mendidik anak agar dapat berdiri sendiri. Dalam dunia pendidikan, ditemukan banyak definisi yang diberikan oleh ahli mengenai pola asuh. Wahyuning (2003) yang menggambarkan pola asuh sebagai seluruh perlakuan orang tua yang ditetapkan pada anak, yang merupakan bagian penting dan mendasar dalam menyiapkan anak untuk menjadi masyarakat yang baik. Hetherington \& Whiting (1999), menyatakan bahwa pola asuh merupakan proses interaksi total antara orang tua dengan anak, seperti proses pemeliharaan, pemenuhan kebutuhan fisik, perlindungan dan proses sosialisasi anak dengan lingkungan sekitar. Menurut Gunarsa (2002) pola asuh orang tua secara lebih lengkap sebagai pola interaksi antara anak dengan orang tua yang meliputi bukan hanya pemenuhan kebutuhan fisik (makan, minum, pakaian dan lain-lain) dan kebutuhan psikologis (afeksi) tetapi juga norma-norma yang berlaku dimasyarakat agar anak dapat hidup selaras dengan lingkungan.

Dari beberapa pendapat-pendapat para ahli diatas. Dapat ditarik kesimpulan. Pola asuh adalah suatu proses interaksi total orang tua dan anak, yang meliputi kegiatan seperti memelihara, memberi makan, melindungi, dan mengarahkan tingkah laku anak selama masa perkembangan serta memberi pengaruh terhadap perkembangan kepribadian anak agar anak dapat hidup selaras dengan lingkungan.

Darling \& Steinberg menyebut adanya tiga factor utama yang mempengaruhi pola asuh yaitu: 1. Hubungan emosional antara orang tua dan anak (seperti ekspresi emosi, tinggi rendahnya suara). 2. Perilaku keseharian yang biasa ditampilkan orang tua 
didepan anak-anak. 3. Sistem keluarga yang dianut oleh orang tua (anak dalam keluarga). Dengan demikian, iklim keluarga menjadi unit terpenting dalam pola asuh. Hal ini juga karena keluarga, sebagaimana dijelaskan oleh Freindman et al., (1998) memiliki lima fungsi dasar, yaitu: fungsi afektif, fungsi sosialisasi, fungsi perawatan atau pemeliharaan kesehatan, fungsi reproduksi, dan fungsi ekonomi.

Baumrind menetapkan empat dimensi pola asuh. Hal ini merupakan cerminan dari responsiveness dan demandingness. Keempat dimensi tersebut adalah: pertama, control yang merupakan bentuk dari konsistensi penegakan aturan, penyediaan struktur kegiatan anak-anak, dan ketekunan dalam memperoleh kepatuhan anak; kedua, pengasuhan yang mencerminkan ekspresi kehangatan dan persetujuan serta perlindungan baik fisik maupun emosional anak-anak; ketiga, kejelasan komunikasi yang merupakan ukuran sejauh mana orang tua melibatkan pendapat dan perasaan anak-anak, dan sejauh mana mereka menggunakan penalaran untuk memperoleh kepatuhan; keempat, tuntutan kedewasaan yang merupakan bentuk dari adanya harapan dan tuntutan terhadap anak. Menurut penelitian Baumrind, mayoritas orang tua menampilkan satu tipe pola asuh terhadap anaknya (meski kadang juga menerapkan lebih dari satu tipe namun ada satu tipe yang dominan). Klasifikasi atas tipe pola asuh, dalam penilaian Baumrind ditentukan dari tingkat respon dan control orang tua terhadap anaknya.

Adapun tipe-tipe pola asuh yakni pola asuh otoriter, pola asuh otoratif, pola asuh permisif, dan pola asuh penelantaran. Pola asuh otoriter, yaitu pola asuh yang memasang batasan-batasan yang ketat, merapkan paksaan dan hukuman serta pada umumnya meyakini bahwa anak harus patuh kepada orang secara total. Dalam pola asuh ini, anak tidak diberi kesempatan untuk memperoleh haknya. Pola asuh otoratif, yaitu pola asuh yang menerapkan aturan-aturan dan batasanbatasan seperti pola asuh otoriter. Namun, standar yang dibuat jelas diketahui anakanaknya, terbuka, responsif dan memahami kebutuhan anak. Pola asuh permisif, yaitu pola asuh yang memberikan kebebasan anak untuk melakukan sesuatu tanpa pengawasan yang cukup. Dalam pola ini, anak berhak menentukan apa yang akan ia lakukan dan orang tua memberikan fasilitas sesuai keinginan anak. Pola asuh penelantar yaitu, pola asuh minimnya bahkan tidak adanya kepedulian orang tua terhadap urusan dan kepentingan anak-anaknya. Bukan berarti orang tua tidak memenuhi kebutuhan anaknya. Hanya saja, orang tua tidak memberikan dorongan emosional. Adapun faktor -faktor yang mempengaruhi pola asuh yaitu : Kultur dan agama, kepribadian, latar belakang orang tua, status sosio-ekonomi, tempramen anak, jenis kelamin anak, usia, dan media massa.

Kemandirian adalah kemampuan untuk mengelola semua yang dimilikinya sendiri yaitu mengetahui bagaimana mengelola waktu, berjalan dan berfikir secara mandiri, disertai dengan kemampuan dalam mengambil resiko dan memecahkan masalah. Dengan kemandirian tidak ada kebutuhan untuk mendapat persetujuan orang lain ketika hendak melangkahmenentukan sesuatu yang baru. Individu yang mandiri tidak dibutuhkan yang detail dan teru menerus tentang bagaimana mencapai produk akhir, ia bias bersandar pada diri sendiri. Kemandirian berkenaan dengan pribadi yang mandiri, kreatif dan mampu berdiri sendiri yaitu memiliki kepercayaan diri yang bias membuat seseorang mampu sebagai individu untuk beradaptasi dan mengurus segala hal dengan dirinya sendiri (Parker, 2006).

Tentang ciri kemandirian Gea (2002, hlm: 145) menyebutkan beberapa hal ciri-ciri kemandirian. Beberapa hal tersebut yakni percaya diri, mampu bekerja sendiri, menguasai keahlian dan keterampilan, menghargai waktu dan bertanggung jawab.

Menurut Hurlock (1990) faktor-faktor yang mempengaruhi kemandirian adalah:

a. Pola asuh orang tua

Orang tua dengan pola asuh demokratis sangat merangsang kemandirian anak, dimana orang tua memiliki peran sebagai pembimbing yang memperhatikan setiap aktivias dan kebutuhan anak, terutama yang berhubungan dengan studi dan 
pergaulannya baik dilingkungan keluarga maupun sekolah.

b. Jenis kelamin

Anak yang berkembang dengan tingkah laku maskulin lebih mandiri dibandingkan dengan anak yang mengembangkan pola tingkah laku yang feminism. Karena hal tersebut laki-laki memiliki sifat yang agresif dari pada anak perempuan yang sifatnya lemah lembut dan pasif.

c. Urutan anak dalam keluarga

Anak pertama sangat diharapkan untuk menjadi contoh dan menjaga adiknya lebih berpeluang untuk mandiri dibandingkan dengan anak bungsu yang mendapatkan perhatian lebih dari orang tua dan saudarasaudaranya berpeluang kecil untuk mandiri.

Faktor-faktor yang menjadi kendala perkembangan kemandirian (Markum, 1985) antara lain:

a. Kebiasaan selalu dibantu dan dilayani.

b. Sikap orang tua yang selalu bersikap memanjakan dan memuji anak akan menghambat kemandiriannya.

c. Kurangnya kegiatan diluar rumah, disaat anak tidak mempunyai kegiatan dengan teman-temannya akan membuat anak bosan sehingga dia akan menjadi malas tidak kreatif serta tidak mandiri.

d. Peranan anggota lain, misalnya ada saudara yang melakukan tugas rumahnya maka akan menghambat kemandiriannya.

\section{METODE PENELITIAN}

Sesuai dengan masalah dan tujuan penelitian, maka penelitian ini menggunakan metode diskriptif korelasional. Populasinya adalah siswa kelas B TK PGRI Gerunung sebanyak 15 anak didik. Sampel yang digunakan sebanyak 8 anak didik. Teknik sampling yang digunakan adalah random sampling. Metode pengumpulan data dengan observasi, angket/ wawancara dan dokumentasi. Teknik analisis data yang dipakai menggunakan analisis statistik dengan korelasi Produk Momen, dimana variabel lain dianggap konstan.

\section{HASIL PENELITIAN}

1. Hubungan pola asuh orang tua dengan tingkat kemandirian anak didik

Dari hasil analisis data pengaruh pola asuh orang tua terhadap kemandirian anak kelompok B TK PGRI Gerunung Praya Kabupaten Lombok Tengah Tahun Pelajaran 2017 /2018 diperoleh rxy sebesar $-0,77$ selanjutnya dikonsultasikan denan $\mathrm{r}$ tabel dengan $\mathrm{N}=20$ dalam taraf signifikansi $5 \%$ dan $1 \%$ yaitu 0,444 dan 0 , 561. Jadi dapat disimpulan bahwa $r$ hitung lebih besar atau $0,444<+0,77>0,561$.

Berdasarkan hasil analisis data diatas, maka hipotesis yang menyatakan "Ada Pengaruh Pola Asuh Orang Tua Terhadap Kemandirian Anak kelompok B TK PGRI Gerunung Tahun Peljaran 2017/2018"terbukti kebenarannya baik pada taraf signifikansi 5\% dan $1 \%$.

Dengan demikian, setiap tipe pengasuhan pasti memiliki resiko masingmasing. Tipe otoriter memang memudahkan orang tua, karena tidak perlu bersusah payah untuk bertanggung jawab dengan anak. Anak yang dibesarkan dengan pola asuh seperti ini mungkin memang tidak memiliki masalah dengan pelajaran dan juga bebas dari masalah kenakalan remaja. Akan tetapi cenderung tumbuh menjadi pribadi yang kurang memiliki kepercayaan diri, kurang kreatif, kurang dapat bergaul dengan lingkungan sosialnya, ketergantungan kepada orang lain, serta memiliki defresi yang lebih tinggi. Sementara pola asuh laissez faire, membuat anak merasa boleh berbuat sekehendak hatinya. Anak memang akan memiliki rasa percaya yang lebih besar, kemampuan sosial baik, dan tingkat kemandirian tinggi. Namun, mungkin terlibat dalam kenakalan remaja dan memiliki prestasi yang rendah di sekolah. Anak tidak mengetahui norma-norma sosial yang harus dipatuhinya (Mohammad Shochib: 1998: 42).

Anak membutuhkan dukungan dan perhatian dari keluarga dalam menciptakan karyanya. Karena itu, pola asuh yang dianggap lebih cocok untuk membantu anak mengembangkan kreativitasnya adalah otoratif atau biasa lebih dikenal dengan demokratis. Dalam pola asuh ini, orang tua memberi control terhadap anaknya dalam batas-batas tertentu, aturan untuk hal-hal yang esensial saja, dengan tetap menunjukkan dukungan, cinta dan kehangatan kepada anaknya. Melalui pola asuh ini anak juga dapat merasa bebas mengungkapkan 
kesulitannya, kegelisahannya kepada orang tua karena ia tahu, orang tua akan membantunya mencari jalan keluar tanpa berusaha mendiktenya (Mohammad Shochib: 1998: 44).

\section{KESIMPULAN}

Berdasarkan dari hasil analisis data pola asuh orang tua dapat mempengaruhi kemandirian anak kelompok B TK PGRI Gerunung tahun Pelajaran 2017/2018 diperoleh rxy sebesar 0,77. Selanjutnya dikonsultasikan dengan $r$ tabel dengan $\mathrm{N}=20$ dalam taraf signifikansi $5 \%$ dan $1 \%$ yaitu 0,444 dan 0,561 (variabel lain diangggap konstan).

Jadi dapat disimpulkan bahwa hipotesis kerja yang menyatakan "Ada Pengaruh Pola Asuh Orang Tua Terhadap Kemandirian Anak Kelompok B TK PGRI Gerunung Praya Tahun Pelajaran 2017/2018 diterima karena teruji kebenarannya.

\section{SARAN}

1. Dari Pihak Sekolah

Bagi sekolah hendaknya menyediakan buku penghubung sebagai acuan orang tua untuk mengetahui perkembangan anaknya di sekolah TK .Diadakan kegiatan parenting setiap bulan agar orang tuanya tahu perkembangan anaknya,

2. Bagi Guru

Guru hendaknya dalam mendidik anak selalu aktif menyampaikan keadaan yang sebenarnya tentang perkembangan anak di sekolah terutama dari segi kemampuan fsik,percaya diri, tanggung jawab anak ,kedisiplinan ,dan interaksi antar teman.

3. Bagi Orang Tua

Orang tua harus lebih pro aktif menanyakan dan mencari informasi tentang perkembangan anaknya kepada guru di sekolah.

\section{DAFTAR PUSTAKA}

A.I.Tridonanto,2002.Menjadikan Anak Berkarakter.Jakarta: Elex Media Komputindo, Gramedia.

Anonim.2014.Pola Asuh Demokratis.Jakarta : Elex Media Komputindo,Gramedia

Fadjeri,2011.Statistik I.Surakart: Fakultas Keguruan Ilmu Pendidikan, Universitas Slamet Riyadi

Maemunah Hasan, 2012.Pendidikan Anak Usia Dini Edisi 7.Yogyakarta:Diva Pres

Maria Montessori, (Editor Gerald Lee Gutex) 2013.Metode Montessori. Yogyakarta: Pustaka Pelajar

Muhyidin. 2014. Ensiklopedia Pendidikan Anak Usia Dini Pendidikan Orang Tua Jilid 7. Yogyakarta:Pustaka Insani Madani

Poerwadarminta,1982.Kamus Umum Bahasa Indonesia.Jakarta:Balai Pustaka

Sugiyono,2015.Metode Penelitian Kuantitatif Kualitatif dan $R \& D$.Bandung: Alfabeta

Suharsini Arikunto,2013.Prosedur Penelitian Suatu Pendekatan Praktek. Jakarta,Rineka Cipta.

Syaiful Bahri Djamarah,2014.Pola Asuh Orang Tua dan Komunikasi dalam keluarga dalam keluarga.Jakarta:Rineka Cipta. 